\title{
Bonding Characterization between 316L and Porous Stainless Steel Pipes by Vacuum Brazing
}

\author{
Li Yaning, Kang Xinting, Wang Jian, Tang Huiping \\ State Key Laboratory of Porous Metal Materials, Northwest Institute for Nonferrous Metal Research, Xi'an 710016, China
}

\begin{abstract}
Vacuum brazing between porous stainless steel (PSS) tube and 316L stainless steel has been performed using BNi-7 brazing paste as a filler metal. And the interface microstructure of the joint was analyzed by SEM and EDS. The results show that $\mathrm{Ni}(\mathrm{Cr}, \mathrm{Fe})-\mathrm{P}$ intermetallic compounds and chromium-rich nickel-iron-based solid solutions phases are the main phases in the brazing seam. The wettability of the molten braze alloy to PSS is better than that to $316 \mathrm{~L}$. The molten braze filler is pulled into the pore of PSS by a capillary action during brazing. The highest tensile strength of $245 \mathrm{MPa}$ is acquired from the joint brazed at $980{ }^{\circ} \mathrm{C}$ for $15 \mathrm{~min}$. Longer processing time or higher processing temperature does not improve the joint strength further.
\end{abstract}

Key words: 316L stainless steel; porous stainless steel; vacuum brazing; BNi-7 filler; tensile strength

Nowadays, porous metals (PM) gain more and more attention due to their excellent structural and functional properties, such as diesel particulate filters, metallic substrate catalytic converters, exhaust gas recirculation coolers (EGR) and more recently heat recovery systems and similar devices using the waste heat of the exhaust gas ${ }^{[1-3]}$. However, it is possible to increase further use of PM by exploiting the ability to manufacture complex geometrical configurations by joining PM parts to one another or to other cast/wrought products.

Several approaches were used for joining dense stainless steel, such as electron beam ${ }^{[4]}$, gas tungsten $\operatorname{arc}^{[5]}$, and laser welding $^{[6]}$, which was reported to be easy handing and producing high performance joints. However, these methods are susceptible to cracking in the heat affected zone and resulting in porous base metal distortion due to their porosity during welding ${ }^{[7-9]}$. In particular, the limited area of inter-particle bonding may produce low ductility adjacent to the joint. Hence these sites may be unable to resist the thermal stresses generated as a result of contraction in a fusion weld.

C. Selcuk proposed that the solid state processes such as diffusion bonding and brazing have been predominantly used for lower density porous parts ${ }^{[10]}$. Compared with other joining processes, vacuum brazing has many advantages, such as relatively lower joining temperature, reduced oxidation, and lower distortion of the base metal. Thus, it is a potential bonding process for joining porous stainless steel (PSS). Recently, Che-Yuan Hsu investigated the bonding properties of $316 \mathrm{~L}$ and PSS by vacuum brazing using Ag-Cu-Ti as filler metal. His results showed that the cracks can be found both in the samples prepared by plasma arc welding and laser welding and no crack formed during the vacuum brazing process ${ }^{[11]}$.

Stainless steel has a wide variety of suitable brazing alloys. So far, copper, silver and nickel based alloy have been successfully developed ${ }^{[12-15]}$.

When silver alloys are used as the filler material, $\mathrm{Ag}-\mathrm{Cu}$ and $\mathrm{Ag}-\mathrm{Cu}-\mathrm{Ti}$ alloys is not wetting to stainless steel. The phenomena of wetting are very important to the formation of brazed joints. Not wetting to stainless steel does not meet the high strength requirements. Sn and $\mathrm{Ti}$ is used as an alloying element to ensure a good flow and wetting ${ }^{[16]}$.

Although copper filler metal is generally preferred because of its low cost and high strength of the joints produced, copper is not recommended for exposure to certain corrosive substances, such as the sulfur in jet fuel and in sulfur-bearing atmosphere ${ }^{[17]}$. 
The greatest advantage of nickel alloys filler metals over commercially available filler metals is high strength even at elevated temperature. Another advantage is excellent resistant corrosion ${ }^{[18,19]}$.

Due to the high strength requirements at elevated temperature in a possibly corrosive environment, a nickel brazing alloy was chosen for use in our application. To minimize the porous base metal distortion and residual stress, brazing temperature must be lower than the sintering temperature of PSS tube $\left(980^{\circ} \mathrm{C}\right)$. In widely employed nickel filler metal group, BNi-7 filler metal is the ideal choice for protective atmosphere furnace brazing because of three factors: (i) compatibility with almost every base material; (ii) low brazing temperature; (iii) high corrosion resistance. The microstructure and mechanical properties of PSS tube joint vacuum brazed with $\mathrm{BNi} 7$ as the filler material were investigated.

\section{Experiment}

The base metal used in the experiment was commercially available $316 \mathrm{~L}$ stainless steel tube, which has the outer diameter of $6 \mathrm{~mm}$, and the length of $20 \mathrm{~mm}$. PSS tube was prepared by powder metallurgy, which has diameter of 5.5 $\mathrm{mm}$ and length of $60 \mathrm{~mm}$. The nominal composition of base metal is specified in Table 1. The filler metal selected for the present investigation was brazing powder $\mathrm{BNi}-7$ (the chemical composition is also given in Table 1). This nickel based powder contains solidification depressants such as phosphorus that lower the brazing temperature and provide a high fluidity. To produce the filler metal in paste form, the binder, which is a water-based gel suspending agent, was mixed with the $\mathrm{BNi}-7$ powder. The solidus and liquidus temperature of $\mathrm{BNi}-7$ was $888{ }^{\circ} \mathrm{C}$. The preferred brazing temperature was from $930{ }^{\circ} \mathrm{C}$ to $1000{ }^{\circ} \mathrm{C}$. As the brazing assembly was tightly fitted in the iron jig, the gap between two tubes was maintained constant, equal to about $60 \mu \mathrm{m}$. The thickness of entire brazing seam was about $0.5 \mathrm{~mm}$.
Vacuum brazing process was carried out under the vacuum of $5 \times 10^{-3} \mathrm{~Pa}$ and leak rate was less than $10^{-2} \mathrm{~Pa} / \mathrm{s}$ with the heating rate of $10{ }^{\circ} \mathrm{C} / \mathrm{min}$.

Base material and joint microstructures were characterized by optical microscopy (OM), scanning electron microscopy (SEM), X-ray diffraction (XRD), and energy dispersive spectroscope (EDS). Tensile tests of the tubes were performed to evaluate the bonding strength of the brazed joint. Each tensile specimen was prepared as illustrated schematically in Fig.1. The specimens were tested on a $100 \mathrm{kN}$ Instron 5892 universal testing machine with a constant speed of $0.3 \mathrm{~mm} / \mathrm{s}$. The experimental data were averaged from at least three measurements for each brazing condition.

\section{Results and Discussion}

\subsection{Joint morphology and EDS analysis}

Fig. 2 is SEM image of cross-section of the brazing seam brazed at $980{ }^{\circ} \mathrm{C}$ for $15 \mathrm{~min}$. Four color contrasts (marked 1, 2, 3 and 4) can be distinguished in the joint region. The compositions of the four color contrasts were measured by EDS and the results are shown in Table 2. According to Table 2, at zone 1, Fe content is $13.22 \%$, which is far higher than that in $\mathrm{BNi}-7$ (0.2\%); At zone 2, Cr content is $30.54 \%$, which is far higher than that in $\mathrm{BNi}-7$ (14\%). The increase of $\mathrm{Fe}$ (zone 1) and $\mathrm{Cr}$ (zone 2) elements in the center of joint seam suggests that the elements in base metal have also diffused into the filler alloy.

The XRD pattern of brazing seam center is shown in Fig.3. The diffraction peaks of (210), (211) and (222) indicate $\mathrm{Ni}(\mathrm{Cr}, \mathrm{Fe})-\mathrm{P}$ intermetallic compounds. Also, chromium-rich nickel-iron-based solid solutions phase appears as shown in diffraction peaks of (111) (400) and (321).

The interface microstructures between PSS and joint seam and that between $316 \mathrm{~L}$ and joint seam are shown in Fig.4a and Fig.4b, respectively. In Fig.4a, the wettability of the molten braze alloy to PSS is better than that to $316 \mathrm{~L}$.

Table 1 Nominal composition of base material and nickel based filler metal (at \%)

\begin{tabular}{cccccccccccc}
\hline Material & $\mathrm{C}$ & $\mathrm{Si}$ & $\mathrm{Mn}$ & $\mathrm{P}$ & $\mathrm{S}$ & $\mathrm{Mo}$ & $\mathrm{B}$ & $\mathrm{Ni}$ & $\mathrm{Cr}$ & $\mathrm{Fe}$ \\
\hline PSS & 0.021 & 0.53 & 1.39 & 0.027 & 0.01 & 2.16 & - & 10.74 & 17.02 & Bal. \\
316L & 0.014 & 0.6 & 1.18 & 0.03 & 0.002 & 2.06 & - & 12.15 & 17.33 & Bal. \\
BNi-7 & 0.06 & 0.01 & 0.04 & 10 & 0.02 & - & 0.01 & Bal. & 14.0 & 0.2 \\
\hline
\end{tabular}

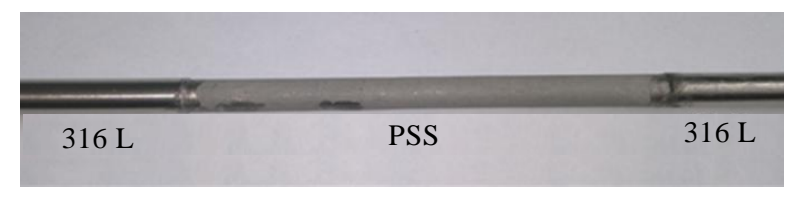

Fig.1 Photograph of tensile testing sample
The molten brazed filler is pulled into the pore of PSS by a capillary action during brazing. The pore of PSS is relatively small ( $\sim \mathrm{um})$, and the capillary action may sufficiently cause the braze filler to infiltrate completely into the porous material interior, which thereby facilitates element interdiffusion between filler and base material. 


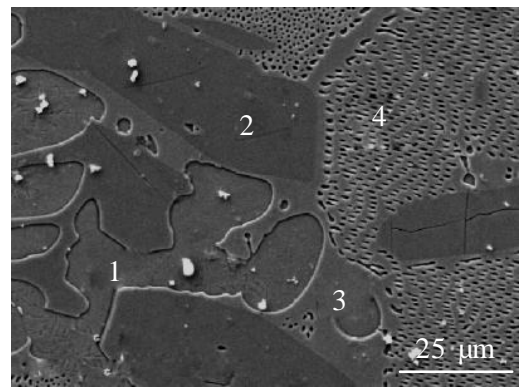

Fig.2 SEM image of cross-section of brazing seam center joined at $980{ }^{\circ} \mathrm{C}$ for $15 \mathrm{~min}$

\begin{tabular}{ccccc} 
Table 2 & \multicolumn{4}{c}{ EDS results of each micro-zone in Fig.2 (at \%) } \\
\hline Zone & $\mathrm{P}$ & $\mathrm{Cr}$ & $\mathrm{Fe}$ & $\mathrm{Ni}$ \\
\hline 1 & 0.84 & 12.98 & 13.22 & 72.96 \\
2 & 19.88 & 30.54 & 3.05 & 46.53 \\
3 & 13.51 & 10.12 & 4.45 & 71.92 \\
4 & 12.15 & 9.64 & 5.31 & 72.90 \\
\hline
\end{tabular}

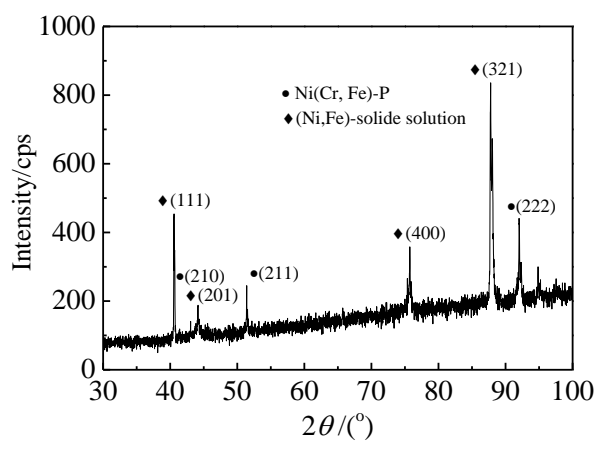

Fig.3 XRD pattern of brazing seam center

The compositions of each zone (marked 1, 2 and 3,4) in Fig.4a and Fig.4b were measured and the results are shown in Table 3. P content at zone 2 is $0.35 \%$, which is far lower than that in $\mathrm{BNi}-7$ (10\%); $\mathrm{P}$ content at zone 3 is $1.01 \%$, which is also far lower than that in BNi-7 (10\%). P content in the brazing seam $(1.01 \%)$ is higher than that in the interface between base metal and joint seam (0.35\%), which may be caused by the relatively poor wettability of phosphorus on stainless steel.

\subsection{Joint tensile strength}

The tensile strength of the joints depending on the processing temperature and time is shown in Fig.5. Fig.5a shows the tensile strength of joints brazed for $15 \mathrm{~min}$ (15 min is the optimal brazing duration for achieving the highest mechanical properties) as a function of the brazing temperature. As can be seen, the tensile strength of the tested samples increases steadily with increasing brazing temperature when the temperature is below $980{ }^{\circ} \mathrm{C}$. At 980 ${ }^{\circ} \mathrm{C}$, the tensile strength reaches the maximum values of 245

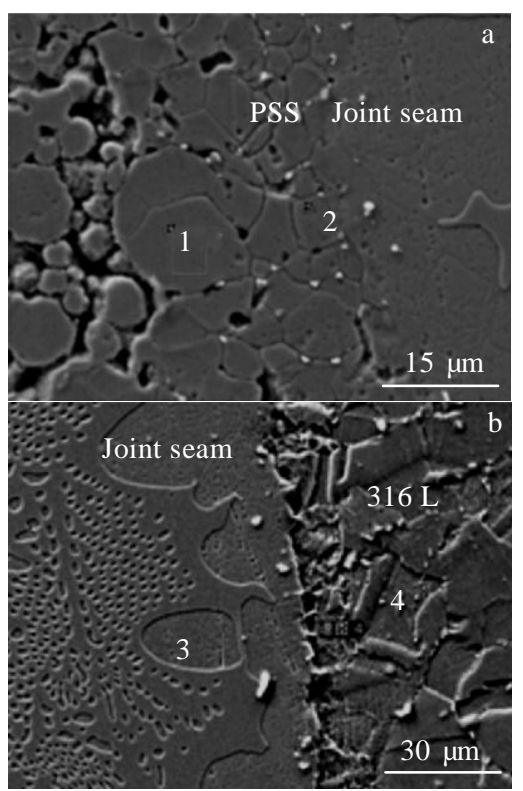

Fig.4 Interface morphologies between PSS and joint seam (a); 316L and joint seam (b)

Table 3 EDS results of each micro-zones in Fig.4 (at\%)

\begin{tabular}{cccccccc}
\hline Zone & $\mathrm{P}$ & $\mathrm{Cr}$ & $\mathrm{Fe}$ & $\mathrm{Ni}$ & $\mathrm{Mn}$ & $\mathrm{Mo}$ & $\mathrm{Si}$ \\
\hline 1 & - & 16.61 & 69.15 & 11.11 & 1.19 & 2.18 & 0.27 \\
2 & 0.35 & 16.67 & 67.41 & 12.38 & 1.12 & 1.69 & 0.38 \\
3 & 1.01 & 17.20 & 64.96 & 12.13 & 1.12 & 2.12 & 0.56 \\
4 & - & 17.31 & 65.58 & 13.82 & 0.06 & 2.56 & 0.67 \\
\hline
\end{tabular}
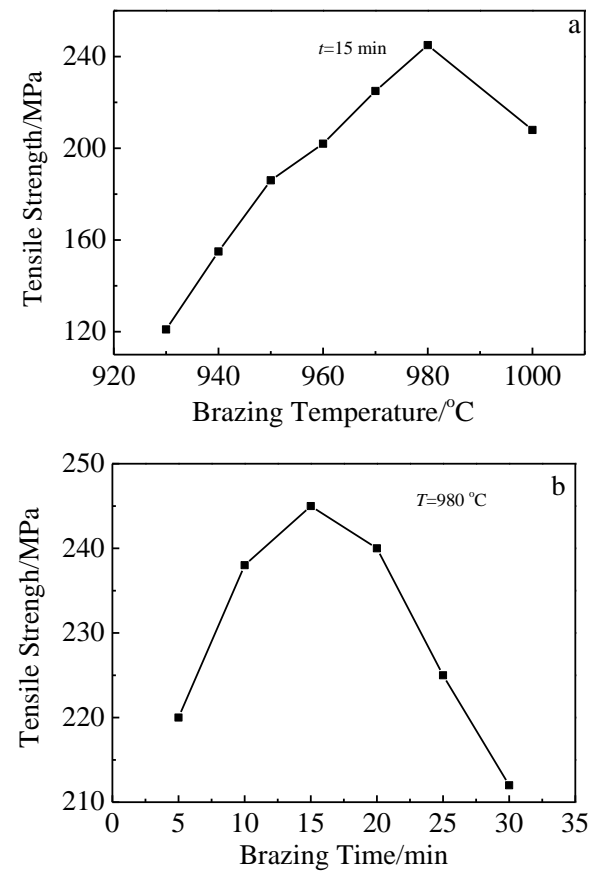

Fig.5 Effects of brazing temperature (a) and brazing time (b) on tensile strength of brazed joints 


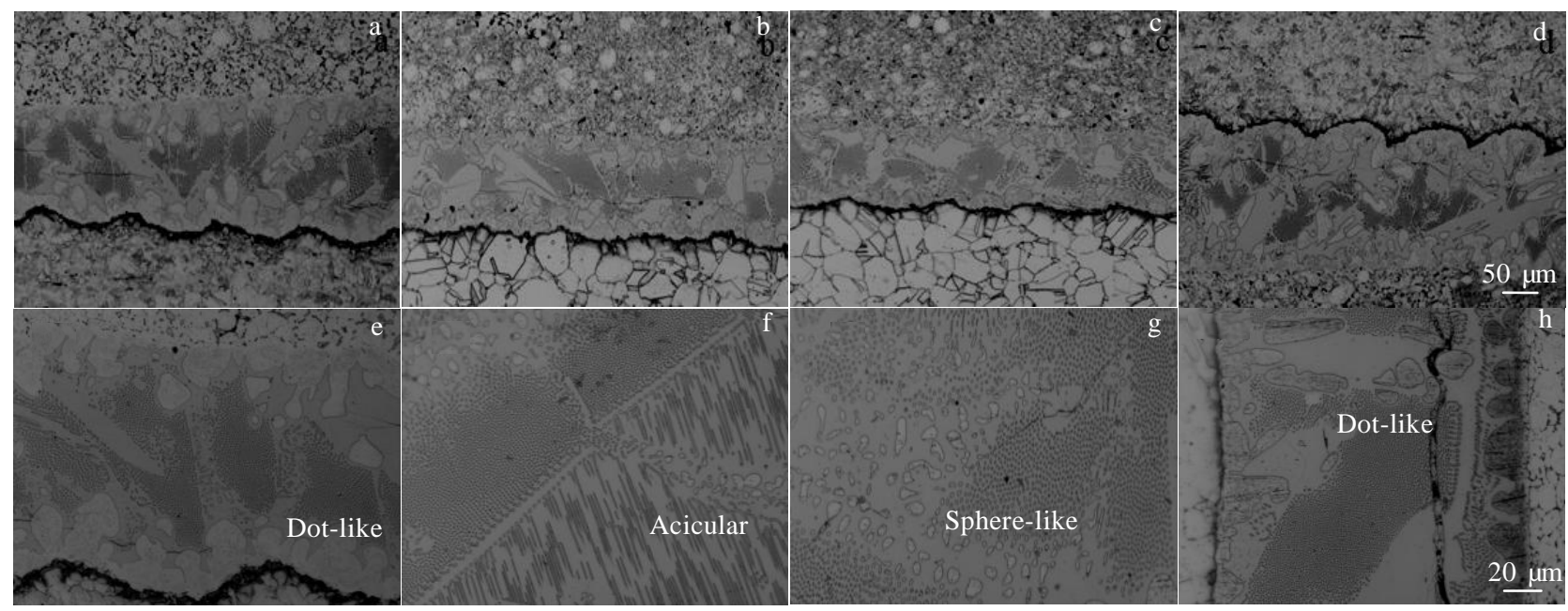

Fig.6 Interfacial microstructures of joint brazed for $15 \mathrm{~min}$ at different temperatures: (a, e) $940{ }^{\circ} \mathrm{C}$, (b, f) $960{ }^{\circ} \mathrm{C},(\mathrm{c}, \mathrm{g}) 980{ }^{\circ} \mathrm{C}$, and $(\mathrm{d}, \mathrm{h})$ $1000{ }^{\circ} \mathrm{C}$

$\mathrm{MPa}$, which is $113.9 \%$ of the porous stainless steel (215 $\mathrm{MPa}$ ). Beyond $980{ }^{\circ} \mathrm{C}$, brazing temperature will be higher than the sintering temperature of PSS tube, and such a high temperature heating process may deteriorate the porous base metal properties, decreasing tensile strengths.

Fig.5b gives the tensile strength of joints at $980{ }^{\circ} \mathrm{C}$ (as can be seen from Fig.5a, brazing at $980{ }^{\circ} \mathrm{C}$ gives the highest tensile strength) as a function of brazing duration. As can be seen, with increasing brazing time from $5 \mathrm{~min}$ to $15 \mathrm{~min}$, the tensile strength increases. However, the tensile strength of joints decreases when the brazing duration is beyond 15 $\min$

\subsection{Microstructure studies}

Optical micrographs of the microstructures of the joint interface for different brazing temperatures are presented in Fig.6a 6d. It is shown that the joint seams for all specimens are excellent wetting between the filler and the base material. Microstructures examination of joint samples at variable temperatures $\left(940,960,980\right.$ and $\left.1000{ }^{\circ} \mathrm{C}\right)$ reveal that higher temperatures samples (980 and $1000{ }^{\circ} \mathrm{C}$ ) produce braze fillets with fewer brittle intermetallic phases compared with lower temperatures samples $\left(940,960{ }^{\circ} \mathrm{C}\right)$. For higher processing temperature, the shape and quantity of intermetallic compounds varies from dot-like to acicular, and sphere-like as shown in Fig.6e 6g. Moreover, precipitation shape of intermetallic compound in brazing seam central depends on brazing temperature. This variation can be attributed to the more P element melting or dissolving in the joint seam with temperature increasing. Joining at $980{ }^{\circ} \mathrm{C}$, specimens contain fewer intermetallic compound phase within a more ductile solid solution phase in centerline, which have greater ductility, enhencing ultimate tensile strength.

\section{Conclusions}

1) $\mathrm{Ni}(\mathrm{Cr}, \mathrm{Fe})-\mathrm{P}$ intermetallic compound and chromium-rich nickel-iron-based solid solution phase are the main phases in the brazing seam. The wettability of the molten braze alloy to PSS is better than that to $316 \mathrm{~L}$. The molten braze filler is pulled into the pore of PSS by a capillary action during brazing.

2) The maximum tensile strength of joint is $245 \mathrm{MPa}$ (113.9\% of that of the PSS), which can be achieved by processing at $980{ }^{\circ} \mathrm{C}$ for $15 \mathrm{~min}$. Longer processing time or higher processing temperature dose not improve the joint strength further.

\section{References}

1 Philip P S, Richard C D, Rick W S et al. Chemical Engineering Research and Design[J], 2015, 102: 69

2 Yan Yan, Reza Bateni, Jeffrey Harris et al. Surface and Coatings Technology[J], 2015, 272: 415

3 Rui Wenjie, Zhang Chun, Cai Chao et al. Journal of Membrane Science [J], 2015, 489: 90

4 Hamill J A, Jr: Weld J[J], 1993(2): 37

5 Subodh Kumar, Shahi A S. Materials and Design[J], 2011, 32 : 3617

6 Yan Jun, Gao Ming, Zeng Xiaoyan. Opt Lasers Eng[J], 2010, 48: 512

7 Kuryntsev S V, Gilmutdinov A K. Journal of Constructional Steel Research[J], 2015, 114: 305

8 Zhang X, Chen W, Bao G et al. Sci Technol Weld Join[J], 2004, 9(4): 376

9 Sgobba S, Daniellou T. Journal of Materials Processing Technology[J], 2003, 143-144: 578

10 Selcuk C, Bond S, Woollin P. Powder Metallurgy[J], 2010, 
53(1): 7

11 Hsu Che Yuan. Thesis for Master[D]. Taiwan: National Taipei University of Technology, 2009

12 Gale W F, Butts D A. Sci Technol Weld Join[J], 2004, 9(3): 283

13 Zhang J, Naka M, Fang H Y et al. Science and Technology of Welding and Joining $[J], 2004,9(2): 158$

14 Leinenbach $\mathrm{C}$, Gelder N, Bissig V et al. Science and Technology of Welding and Joining [J], 2007, 12(8): 708

15 Wanjara P, Brochu M, Girard S et al. Materials Science and
Technology[J], 2005, 21(5): 613

16 Roy R K, Bapari H, Panda A K et al. Science and Technology of Welding and Joining [J], 2013, 18(3): 216

17 Li Jr Hung. Thesis for Master[D]. Cincinnati: University of Cincinnati, 2001

18 Craymer Kenneth. Thesis for Master[D]. Cleveland: Case Western Reserve University, 2011

19 Liang D, Sowards J W, Frankel G S et al. Corrosion Science [J], 2010, 52(7): 2439

\title{
多孔不锈钢管与 $316 \mathrm{~L}$ 不锈钢的真空钎焊连接特性
}

\author{
李亚宁, 康新婷, 王 建, 汤慧萍
}

(西北有色金属研究院 金属多孔材料国家重点实验室 陕西 西安 710016)

摘 要: 采用镍基BNi-7焊膏为钎料, 对多孔不锈钢管与316L不锈钢成功实现真空钎焊连接, 并用扫描电子显微镜(SEM)和X射线衍射仪 (XRD)对接头界面组织结构进行观察和分析。结果表明, 钎料对多孔不锈钢的润湿性比对316L的要好。在钎焊过程中, 钎料通过毛细作 用渗透到多孔不锈钢的孔隙中。焊缝的主要相是富 $\mathrm{Cr}$ 的 Ni-Fe基固溶体和Ni-P金属间化合物。测试连接件的整体拉伸性能, 焊接温度 $980{ }^{\circ} \mathrm{C}$ 及焊接时间 $15 \mathrm{~min}$ 得到的焊接件的室温抗拉强度最大，为 $245 \mathrm{MPa}$ 。在同等条件下，延长保温时间或者提高焊接温度都不能进一 步提高焊接强度。

关键词: 316L不锈钢; 多孔不锈钢; 真空钎焊; BNi-7 钎料; 抗拉强度

作者简介: 李亚宁, 女, 1980 年生, 硕士, 高级工程师, 西北有色金属研究院粉末冶金研究所, 陕西 西安 710016, 电话: 029-86231095, E-mail: xiaoxi80625@163.com 